\title{
Os jovens e a vocação matrimonial: ainda uma realidade?
}

\section{Young people and marriage vocation: still a reality?}

\section{Robson Ribeiro de Oliveira Castro*}

Recebido: 09/05/2019. Aprovado: 26/07/2019.

Resumo: O presente artigo tem o intuito de analisar a Exortação Apostólica Pós-sinodal Amoris Laetitia, sobre o amor na família, e a relação da juventude com a vocação matrimonial. Para tanto a proposta do Papa Francisco ao convocar um sínodo para a juventude é ouvir os jovens, seus clamores e angústias. De fato, a Exortação Apostólica Pós-sinodal Christus Vivit sobre a juventude será de grande importância para observarmos o cenário atual da juventude. $\mathrm{Na}$ sociedade hodierna a juventude se sente excluída da vida da Igreja e muitas vezes cansada de tantas normas e questões doutrinais. Francisco apresenta o rosto de Deus que é jovem e uma Igreja que se coloca a serviço. A vocação matrimonial e familiar, assunto que merece atenção, será abarcado nesta temática pois é um dos campos de atuação, por isso o sínodo da juventude e seus documentos nos renovam a proposta de uma Igreja atenta às realidades. A juventude é convocada a assumir seu protagonismo e a vocação matrimonial, o amor conjugal, além de buscar a sua realização na doação em prol do próximo. Como não poderia deixar de ser, veremos esse assunto, também, à luz dos escritos e outros pronunciamentos e catequeses do Papa Francisco. Para endossar nosso posicionamento, buscamos conhecer o pensamento de documentos conciliares que citam esta temática e propõem um protagonismo da juventude.

Palavras-chave: Vocação. Amoris Laetitia. Papa Francisco. Christus vivit.

Abstract: The aim of this article is to analyze the Post-Synodal Apostolic Exhortation Amoris Laetitia on love in the family and the relationship of youth with the vocation of marriage. For this, Pope Francis's proposal when summoning a sy-

* Mestre em Teologia Moral (Faculdade Jesuíta de Filosofia e Teologia - FAJE, Belo Horizonte, 2017). Pós-graduado, lato sensu, em Direito Matrimonial Canônico (Faculdade São Bento - FSB, Rio de Janeiro, 2012). Graduado em História (Centro de Ensino Superior de Juiz de Fora - CESJF, Juiz de Fora, 2011). Professor de Teologia Moral do Instituto Teológico Franciscano, em Petrópolis.

E-mail: robsonrcastro@yahoo.com.br 
nod to youth is to listen to the young people. In fact, the Post-Synodal Apostolic Exhortation Christus Vivit on youth will be the basis of our analysis. The reality of youth is feeling excluded from church life and doctrinal practices. Francis addresses the young people that want to embody church life and to offer their services. The vocation of marriage is a subject matter worth attention. That is why the synod of youth and its documents renews the proposal of a church keen on everyday realities. The youth is called on to assume its protagonism and to assume a marital vocation of conjugal love, as well as to work for the benefit of others. We shall look into this subject in the light of the writings and other pronouncements and catecheses of Pope Francis. To endorse our positioning, we seek to read conciliar documents that propose the protagonism of youth.

Keywords: Vocation. Amoris Laetitia. Pope Francis. Christus Vivit.

\section{Introdução}

A cultura atual, ao promover uma desvalorização dos laços humanos e das relações, enfraquece e coloca em análise a vocação ao matrimônio assumido como um sacramento pelas novas gerações. É importante nos ater ao fato de que vivemos em uma época de relativismo, individualismo e, acima de tudo, de perda de referências. Entretanto, devemos enaltecer as iniciativas e a forma como a juventude pretende assumir a sua vocação e sua missão, deixando de ser meros coadjuvantes e assumindo seu protagonismo.

A união entre homem e mulher, pautada na relação, é uma vocação inserida na história humana desde a Criação, sendo parte do projeto de Deus que cria o ser humano à sua imagem e semelhança. A Exortação Apostólica pós-sinodal Amoris Laetitia, sobre o amor na família, apresenta chaves para se tratar dos problemas e das situações que a família vive, mesmo que as mudanças antropológicas e a propaganda negativa do mundo pós-moderno não favoreçam esta questão. No documento encontramos uma atitude pastoral e misericordiosa. Tal manifestação do Magistério será nosso documento chave para entender as vocações e a missão da família.

Diante disso, nosso objetivo neste artigo é avaliar as seguintes questões: Há ainda desejo das novas gerações em assumir o sacramento do matrimônio? É possível ainda observar famílias que são exemplos para nossa vivência cristã? Importante ressaltar que nosso estudo se restringirá a vocação matrimonial para que seja possível absorver bem o que é dado.

Com este cenário, diante das transformações sociais e dos escritos do Magistério, buscaremos observar essa realidade. Assim enveredamos para o estudo que agora passamos a discorrer. 
A Exortação Apostólica Pós-sinodal Christus Vivit, sobre a Igreja e juventude, é o objeto de pesquisa que nos ajudará a entender o que a Igreja Católica pede à juventude, o clamor do Papa e o caminho a seguir diante de tantas tentações e dificuldades. Apresentaremos alguns aspectos da relação entre a vocação e o matrimônio nas novas gerações, considerando a mudança antropológica da sociedade e o interesse em pautar-se pelo projeto de amor de Deus.

\section{O jovem e a família na contemporaneidade}

Diante da realidade pós-moderna, é possível observar uma diminuição no número de matrimônios, quando os casais optam por coabitar, ou, até mesmo, preferem não se unirem e optam por uma vida solitária: "o grande risco do mundo atual é a tristeza individualista que brota do coração comodista e mesquinho, da busca desordenada de prazeres superficiais, da consciência isolada"1.

Neste contexto, enaltecer a vocação matrimonial é imprescindível, porém não devemos nos fechar e deixar que realidades deixem de ser analisadas. As famílias não podem estar fechadas em si mesmas, devem se abrir e vivenciar o dia-a-dia com outras famílias na sociedade. "A família é um bem de que a sociedade não pode prescindir, mas precisa ser protegida"

$\mathrm{Na}$ Exortação Apostólica Pós-sinodal Amoris Laetitia, é nítido o carinho e zelo do Papa Francisco pelos jovens e suas vocações. Assumindo o papel de pastor e acolhedor, Francisco se debruça para escrever à juventude com o intuito de se fazer ouvir por todos. O Papa, atento à realidade hodierna, se preocupa com a juventude e apresenta sua impressão, mesmo com as dificuldades e os sinais de crise, sobre o sacramento do matrimônio e as novas gerações. O Sucessor de Pedro afirma que

o desejo de família permanece vivo, de forma especial entre os jovens, motivando a Igreja, perita em humanidade e fiel à sua missão, a anunciar incessantemente e com profunda convicção o 'Evangelho da família', que lhe foi confiado mediante a revelação do amor de Deus em Jesus

FRANCISCO. Exortação Apostólica Evangelii Gaudium sobre o anúncio do Evangelho no mundo atual. São Paulo: Loyola, 2013. n. 2. (Daqui em diante = EG)

2 FRANCISCO. Exortação Apostólica Pós-sinodal Amoris Laetitia sobre o amor na família. São Paulo: Paulinas, 2016. n. 44. (Daqui em diante = AL) 
Cristo e ininterruptamente ensinado pelos Padres, pelos Mestres da espiritualidade e pelo Magistério da Igreja. ${ }^{3}$

O ser humano não foi criado para ser sozinho e a vida só tem sentido no amor que, em Deus, se oferece aos homens em tantos dons e vocações. Dessa forma, devemos evitar cair no individualismo, algo que não combina com Deus e que fere diretamente a comunhão.

Transpõe-se para as relações afetivas o que acontece com os objetos e o meio ambiente: tudo é descartável, cada um usa e joga fora, gasta e rompe, aproveita e espreme enquanto serve; depois, adeus. O narcisismo torna as pessoas incapazes de olhar para além de si mesmas, dos seus desejos e necessidades. Mas quem usa os outros, mais cedo ou mais tarde acaba por ser usado, manipulado e abandonado com a mesma lógica. Faz impressão ver que as rupturas ocorrem, frequentemente, entre adultos já de meia-idade que buscam uma espécie de "autonomia" e rejeitam o ideal de envelhecer juntos cuidando-se e apoiando-se. ${ }^{4}$

A Constituição Pastoral Gaudium et Spes, do Concílio Vaticano II, aponta a união conjugal como a institucionalização da vontade de Deus na promoção da família: "por meio do ato humano com o qual os cônjuges mutuamente se dão e recebem um ao outro, nasce uma instituição também à face da sociedade, confirmada pela lei divina"5.

Deus não é tirano, muito menos punitivo, é um Deus do diálogo, misericordioso, que fez o ser humano à sua imagem e semelhança e, durante a história da salvação, propõe-se a escutar o clamor do seu povo.

O jovem necessita que falemos para ele não somente de um Deus que vem de fora, mas também de um Deus que é real dentro dele em seu modo juvenil de ser alegre, dinâmico, criativo e ousado. A evangelização da Igreja precisa mostrar aos jovens a beleza e a sacralidade da sua juventude, o dinamismo que ela comporta, o compromisso que daqui emana, assim como a ameaça do pecado, da tentação do egoísmo, do ter e do poder e, com isto, auxiliar também na conscientização de tudo aquilo que procura danificar esta obra de Deus. Uma verdadeira espiritualidade

3 SíNODO DOS BISPOS. III Assembleia Geral Extraordinária do Sínodo dos Bispos. Os desafios pastorais sobre a família no contexto da evangelização. Relatio Synodi (18 de Outubro de 2014), n. 2. Disponível em: <http://www.vatican.va/roman_curia/ synod/documents/rc_synod_doc_20141018_relatio-synodi-familia_po.html>. Acesso em: 16 abr. 2019.

4 AL, n. 39.

5 GS, n. 48. 
possibilita ao jovem encontrar-se com a realidade sublime que há dentro dele, manter um diálogo constante com aquele que o criou. ${ }^{6}$

Os bispos do Brasil, ao falaram sobre a juventude, afirmam que, "para a Igreja, a juventude é uma prioridade em sua missão evangelizadora" "Tal afirmação é de fato a aceitação do novo e da sua presença marcante na sociedade. A melhor forma de convivência é o diálogo, buscando a construção da confiança dos jovens e um amadurecimento afetivo.

Hoje é, de fato, uma dificuldade manter um diálogo sadio, convicto e bem estabelecido, seja com a juventude, seja em qualquer realidade. Estamos diante de situações de esvaziamento de relações e de falsos valores. Tudo isso compromete a convivência e afasta cada vez mais os indivíduos:

A imersão no mundo virtual propiciou uma espécie de "migração digital", isto é, um distanciamento da familia, dos valores culturais e religiosos, o que leva muitas pessoas a um mundo de solidão e autoinversão, até sentir a falta de raizes, embora fisicamente fique no mesmo lugar. ${ }^{8}$

O Papa Francisco nos convida a pensar a nossa vocação: "O acompanhamento vocacional é dimensão fundamental dum processo de discernimento por parte da pessoa que é chamada a escolher". De fato, somos chamados a ser discípulos de Cristo e seguir o seu projeto de evangelização cumprindo a vocação e o chamado pelo batismo; somos sujeitos da evangelização.

Falar de Deus e da fé do povo deve ser para o jovem uma fase boa e não uma imposição: "A fé há de ser apresentada aos jovens como um encontro amoroso com Deus, que toma feições humanas na pessoa de Jesus Cristo" ${ }^{10}$. Por isso, para a juventude, a vida de Cristo deve ser

6 CONFERÊNCIA NACIONAL DOS BISPOS DO BRASIL. Evangelização da Juventude: Desafios e perspectivas pastorais. São Paulo: Paulinas, 2007. n. 80. (Daqui em diante $=$ CNBB).

7 CNBB, 2007, n. 81.

8 FRANCISCO. Exortação Apostólica Pós-sinodal Christus Vivit, aos jovens e a todo o povo de Deus. São Paulo: Paulinas, 2019. n. 90. (Daqui em diante = CV).

9 SÍNODO DOS BISPOS. XV Assembleia Geral Ordinária. Os jovens, a fé e o discernimento vocacional. Documento Final. 2018, n. 104. Disponível em: <http://www.vatican. va/roman_curia/synod/documents/rc_synod_doc_20181027_doc-final-instrumentum-xvassemblea-giovani_po.html>. Acesso em: 23 abr. 2019. 
um modelo, não de doutrinas e normas, mas de simplicidades e de envolvimento com a família.

A proposta do Cristo, sua vida e seu testemunho são baseados na doação ao outro, conforme é possível observar a sua atuação na comunidade, seus caminhos e paradas, suas andanças pelas mais remotas áreas:

não se deve pensar que Jesus era um adolescente solitário ou um jovem que pensava só em si mesmo. Sua relação com as pessoas era a de um jovem que compartilhava toda a vida de uma família bem integrada na aldeia $^{11}$.

Importante observar que o encontro com o Cristo se dá no momento em que se aceita o seu projeto e ouve-se o seu chamado. Seguir o Ressuscitado é um caminho que se faz ao aceitar o convite a partilhar com Ele uma vida e se colocar em constante observância da sua Palavra.

Auscultar sua Palavra, que renova todo o ser humano é o convite a assumir o projeto e aceitar o chamado à santidade, pois "a juventude é um lugar teológico da comunicação de Deus"12.

Dessa maneira, observar o evento Cristo, o envolvimento dele com seu povo e sua entrega é sinal da jovialidade na Igreja. A relação de Jesus com a sua família e a sociedade de sua época é modelo que corrobora para a ação do jovem na sua realidade. Cristo observava a realidade para seguir os desígnios de seu Pai. Suas atitudes podem se tornar inspiração

para todo jovem que cresce e se prepara para realizar sua missão. Isto implica amadurecer no relacionamento com o Pai, na consciência de ser um dos membros a mais na família e na comunidade, e na abertura para ser plenificado pelo Espírito e conduzido para realizar a missão que Deus solicita, a própria vocação. ${ }^{13}$

Jesus se preocupa em nos apresentar um Pai bondoso e misericordioso, um Pai que olha para seus filhos e se compadece deles. Com esta proposta, Cristo é o caminho que leva ao Pai e nos recorda que este

11 CV, n. 28.

12 CNBB, 2007, n. 118.

$13 \mathrm{CV}, \mathrm{n} .30$. 
sempre está atento às nossas necessidades e olha para nós com um olhar benevolente e misericordioso ${ }^{14}$.

A família está sujeita a muitas questões que podem gerar dificuldades no relacionamento e na vida familiar. Com esta preocupação, devemos voltar nossa atenção aos jovens, pois eles podem sofrer por não serem compreendidos ou não serem ouvidos.

A família adquire para a Igreja uma importância totalmente particular e, no momento em que todos os fiéis são convidados a sair de si mesmos, é necessário que a família volte a descobrir-se como protagonista imprescindivel da evangelização. O pensamento dirige-se ao testemunho missionário de numerosas famílias. ${ }^{15}$

De fato, a família deve assumir o seu lugar de apoiadora, educadora e guia, apresentando ao jovem a sua relação e dando real importância à sua atuação seja no mundo, seja na família. As dificuldades da pós-modernidade e os problemas que a instituição familiar enfrenta não devem desanimar ou desvalorizar o envolvimento familiar. Muito pelo contrário, é necessário alimentar o desejo de assumi-lo.

A história duma família está marcada por crises de todo o gênero, que são parte também da sua dramática beleza. É preciso ajudar a descobrir que uma crise superada não leva a uma relação menos intensa, mas a melhorar, sedimentar e maturar o vinho da união. Não se vive juntos para ser cada vez menos feliz, mas para aprender a ser feliz de maneira nova, a partir das possibilidades que abre uma nova etapa. Cada crise implica uma aprendizagem, que permite incrementar a intensidade da vida comum ou, pelo menos, encontrar um novo sentido para a experiência matrimonial. ${ }^{16}$

É preciso observar, escutar e não se deixar levar pelos discursos prontos que enaltecem os problemas que a família vive e as dificuldades da sociedade moderna. Uma das características cristãs é apresentar lampejos de soluções. Para isso, tem que haver interesse, empenho, dedicação

14 Cf. FRANCISCO. Deus é jovem: uma conversa com Thomas Leoncini. São Paulo: Planeta do Brasil, 2018. p. 124.

15 SÍNODO DOS BISPOS. III Assembleia Geral Extraordinária do Sínodo dos Bispos. Os desafios pastorais sobre a família no contexto da evangelização. Relatio Synodi, n. 2. Disponível em: <http://www.vatican.va/roman_curia/synod/documents/rc_synod_doc_20141018_relatio-synodi-familia_po.html>. Acesso em: 16 abr. 2019. 
e, principalmente, coragem de enfrentar e assumir a família. Assim com o amadurecimento e a liberdade, a família cresce de maneira integral.

\section{O matrimônio e a juventude}

A vocação ao matrimônio é um chamado de entrega que, quando feito reciprocamente, um se compromete com a realidade do outro. Aqueles que o assumem são convidados a responder ao chamado de Deus para se tornarem participantes de sua família enquanto casal, devendo prevalecer a vivência em família e os sentimentos do amor e do matrimônio.

Assim é nossa relação tanto no matrimônio quanto com nossos irmãos e irmãs em Cristo: “O Espírito Santo quer nos impulsionar para que saiamos de nós mesmos, abracemos os outros com o amor e busquemos o seu bem"17. A realização do matrimônio enquanto sacramento precisa que ambas as partes estejam empenhadas na construção do consentimento. Tal tarefa é complexa e, por diversas vezes, pode causar temor aos cônjuges. Entretanto é sempre bom observar que Cristo conhece nossas fraquezas e angústias.

Cristo sabe que os esposos não são perfeitos e que eles precisam superar sua fragilidade e inconstância para que seu amor possa crescer e durar. Por isso, concede aos cônjuges sua graça, que é, ao mesmo tempo, luz e força que lhes permite realizar o seu projeto de vida matrimonial de acordo com o plano de Deus. ${ }^{18}$

Em seus escritos, Francisco abre seu coração e convida os noivos a seguirem o caminho do amor. Ressalta que a preparação deve ser feita de forma continuada e não apenas nas vésperas do casamento. "É necessário preparar-se para o Matrimônio, e isso requer se educar, desenvolvendo as melhores virtudes, especialmente o amor, a paciência, a capacidade de diálogo e de serviço"19.

O matrimônio, diante da realidade e influenciado pela modernidade, busca ainda a valorização da dignidade da pessoa, sem qualquer discriminação: "A idêntica dignidade entre o homem e a mulher impele

\begin{tabular}{ll}
\hline 17 & CV, n. 164. \\
18 & CV, n 266. \\
19 & CV, n. 265.
\end{tabular} 
a alegrar-nos com a superação de velhas formas de discriminação e o desenvolvimento de um estilo de reciprocidade dentro das famílias" ${ }^{\prime 20}$.

Jesus nos apresenta a união dos casais como plenitude da revelação do projeto de Deus. O matrimônio não é uma mera fase da vida, ou um processo social, mas sim um dom para a santificação, é o sinal sacramental da relação de Cristo com a Igreja. "Como cristãos, não podemos renunciar a propor o matrimônio, para não contradizer a sensibilidade atual, para estar na moda, ou por sentimentos de inferioridade face ao descalabro moral e humano"21.

O acolhimento é parte fundamental para os jovens. Eles não devem sentir-se excluídos da comunidade eclesial, pois fazem parte do corpo místico de Cristo e devem ser tratados com respeito. Com esta premissa se faz urgente uma fé engajada e consciente: "é melhor viver a fé juntos e expressar nosso amor em uma vida comunitária, compartilhando com outros jovens nosso afeto, nosso tempo, nossa fé e nossas inquietudes" ${ }^{\prime 22}$.

Tratar os jovens, e toda a comunidade, como corpo de Cristo nos remete ao pensamento de uma eclesiologia do povo, não pautada na hierarquia. O matrimônio é o alicerce de uma relação entre duas pessoas, que se doam mutuamente, a fim de ter uma comunhão para toda a vida e serem fecundos.

O matrimônio tem seu caráter indissolúvel e expressa a decisão real e efetiva de transformar dois caminhos num só, que, por sua vez, é evidenciada na vivência do amor e na entrega, assim como a Santíssima Trindade: "O Deus Trindade é comunhão de amor; e a família, o seu reflexo vivente" ${ }^{23}$. A indissolubilidade não pode ser encarada como uma obrigação, mas um dom de Deus que nos amou primeiro.

A inspiração conciliar aponta, nos documentos do magistério, para a beleza do percurso da vida conjugal. O caminho diário de encontro dos esposos reafirma as promessas sacramentais. $O$ consentimento dado pelos nubentes se torna uma aceitação do projeto de Deus para a vida humana.

[...] os cônjuges cristãos, em virtude do sacramento do Matrimônio, com que significam e participam o mistério da unidade do amor fecundo entre

\footnotetext{
AL, n. 54.

21 AL, n. 35.

22 CV, n. 164.

23 AL, n. 11.
} 
Cristo e a Igreja (Ef. 5,32), auxiliam-se mutuamente para a santidade, pela vida conjugal e pela procriação e educação dos filhos, e têm assim, no seu estado de vida e na sua ordem, um dom próprio no Povo de Deus. ${ }^{24}$

O matrimônio é um dom de Deus. Para tanto, sua indissolubilidade não deve ser um jugo pesado, um fardo que deve ser carregado a duras penas, ou imposto pelos homens, mas deve ser valorizado e encarado com seriedade para não haver a banalização do sacramento.

Precisamos encontrar as palavras, as motivações e os testemunhos que nos ajudem a tocar as cordas mais intimas dos jovens, onde são mais capazes de generosidade, de compromisso, de amor e até mesmo de heroísmo, para convidá-los a aceitar, com entusiasmo e coragem, o desafio de matrimônio ${ }^{25}$.

Na cultura do consumo, as relações não assumem a sua concretude; apressadamente assume-se outro relacionamento, sem mesmo verificar a seriedade de uma caminhada de fé entre o casal, mas apenas para satisfação pessoal. É neste contexto que as famílias vivem uma crise de identidade e passam esses desvalores aos filhos. O testemunho é o maior educador, e, para ser aliado contra a cultura do descartável, é necessária uma caminhada na fé.

O testemunho mais persuasivo da benção do matrimônio cristão é a vida dos esposos cristãos e da família. Não há modo melhor para transmitir a beleza do sacramento! O matrimônio consagrado por Deus preserva o vínculo entre o homem e a mulher que Deus abençoou desde a criação do mundo; e é manancial de paz e bem para toda a vida conjugal e familiar. ${ }^{26}$

Desta forma, o testemunho corrobora para a conversão das novas gerações. "Os jovens são muito sensíveis aos testemunhos, eles precisam de homens e mulheres que sejam exemplos, que façam sem exigir nada dos outros, que se revelem pelo que são e basta." ${ }^{27}$ A busca pelo matrimônio deve ser um caminho consciente, tranquilo e maduro. A verdadeira celebração convida Jesus para estar presente na relação dos dois, pois somente na presença dele é que se fundamenta o sacramento.

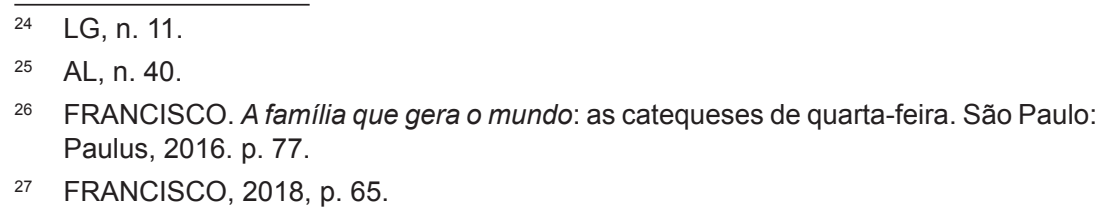


Os noivos não devem pensar que estão casando e que vão viver exclusivamente para si.

O sacramento do matrimônio é um grande ato de fé e de amor: dá testemunho de coragem de acreditar na beleza do gesto criador de Deus e de viver aquele amor que impele a ir sempre além, além de nós mesmos e da própria família. A vocação cristã para amar de modo incondicional e incomensurável é, com a graça de Cristo, o que está também na base do livre consenso que constitui o matrimônio. ${ }^{28}$

A constituição familiar é uma graça ofertada por Deus aos que se propõem a essa vivência. Para tanto, deve-se falar do matrimônio para os jovens casais, buscando uma fala mais atrativa, que, sem deixar de lado questões doutrinais e morais, insista na graça de Deus no amor conjugal, privilegiando, assim, o relacionamento humano. "Ninguém pode pensar que o enfraquecimento da família como sociedade natural fundada no matrimônio seja algo que beneficia a sociedade". ${ }^{29} \mathrm{O}$ matrimônio foi algo querido por Deus, que quer a família como uma instituição fecunda e viva, para o bem da sociedade.

A Igreja busca observar a sua relação temporal com a situação antropológica. De fato, o mistério do indivíduo só se torna claro verdadeiramente no mistério do Verbo encarnado. Deus revela em Jesus Cristo o seu amor pelo ser humano. No grande projeto da Criação e nas suas relações entre si, o ser humano descobre a sua vocação ${ }^{30}$.

Dessa maneira, a juventude é convidada a assumir a sua vocação, o seu protagonismo autêntico na vida e missão da Igreja, pois os jovens devem se fazer ouvir e agir conforme sua vocação. "Os jovens batizados devem ser encorajados a não hesitar diante da riqueza que o sacramento do matrimônio suscita nos seus planos de amor, fortalecidos pelo apoio que recebem da graça de Cristo e da possibilidade de participar plenamente na vida da Igreja" 31 .

28 FRANCISCO, 2016, p. 80.

29 AL, n. 52.

30 Cf. GS, n. 22

31 SíNODO DOS BISPOS. III Assembleia Geral Extraordinária do Sínodo dos Bispos. Os desafios pastorais sobre a família no contexto da evangelização. Relatio Synodi (18 de Outubro de 2014), n. 26. Disponível em: <http://www.vatican.va/roman_curia/ synod/documents/rc_synod_doc_20141018_relatio-synodi-familia_po.html >. Acesso em: 16 abr. 2019. 
De fato, a Igreja caminha para uma proposta de atuação dos jovens na sua realidade, convidando-os a serem atentos às realidades que vivem e à forma como as pastorais sociais atuam. Francisco é enfático ao afirmar: "Deus ama a alegria dos jovens e os convida especialmente a essa alegria de quem vive em comunhão fraterna, a essa satisfação superior de quem sabe compartilhar" ${ }^{\prime 2}$.

Em seu livro Deus é Jovem, Francisco ressalta a necessidade de o jovem caminhar e se colocar em constante serviço e ação: “o jovem sempre tem um pé na frente do outro, pronto para partir, para sair em disparada. Sempre lançado para frente. Falar sobre jovens significa falar de promessas, e isso significa falar de alegria" 33 .

Entretanto, deve-se buscar no discernimento o verdadeiro crescimento pessoal e espiritual, viver em constante acompanhamento, nutrir a misericórdia de Deus em nossos corações. Mesmo na sociedade e nas fragilizadas relações, os jovens devem buscar se empenhar e lutar contra a exclusão e a solidão, malefícios para as relações.

Crescer é conservar e nutrir as coisas mais preciosas que a juventude te dá, mas ao mesmo tempo é estar aberto para purificar o que não é bom e receber novos dons de Deus que te chama a desenvolver o que vale a pena ${ }^{34}$.

Que tenhamos o discernimento, amparados pela Palavra de Deus que ilumina a realidade concreta da vida cotidiana. Não há receitas prontas para a missão, muito menos para a vida em comunidade; é necessário buscar o discernimento, que é apresentado pelo sínodo como "o processo em que se tomam decisões importantes" ${ }^{\prime 3}$.

Porém, atento às mazelas da virada antropológica do mundo pós-moderno, o discernimento deve ser estrutura basilar para o agir moral e sua realidade, pois é assim que evitamos agir de forma equivocada. A Igreja que escuta o seu povo e se coloca atenta às realidades não propõe uma lista de regras ou de condenações, mas um chamado à misericórdia

\footnotetext{
32 CV, n. 167.

33 FRANCISCO, 2018, p. 21.

34 CV, n. 161.

35 SÍNODO DOS BISPOS. XV Assembleia Geral Ordinária. Os jovens, a fé e o discernimento vocacional. Documento Final. 2018, n. 104. Disponível em: <http://www.vatican. va/roman_curia/synod/documents/rc_synod_doc_20181027_doc-final-instrumentum-xvassemblea-giovani_po.html>. Acesso em: 23 abr. 2019.
} 
e ao acompanhamento, pois é a partir de uma família que devemos pautar a sociedade mais humana, fraterna e consciente.

\section{O amor no matrimônio}

A Igreja deve ser o alicerce para o matrimônio e para família, devendo estar atenta às mudanças sociais e culturais. É importante dialogar com os problemas mais diversos apresentados. O clamor da juventude é a sua relação com o protagonismo da Igreja. O sucessor de Pedro é enfático e afirma que "Jesus não gostava de que os adultos olhassem com desprezo para os jovens ou os colocassem a seu serviço de maneira despótica" 3 . Ao contrário, Jesus queria que nos colocássemos como crianças e não procurássemos ser o maior entre todos, mas sim o menor $^{37}$.

Nesse escopo, Francisco diz que a juventude se cansa da forma como a Igreja age com eles: "Muitos jovens se cansam de nossos itinerários de formação doutrinal, e até mesmo espiritual, e, às vezes, reivindicam a possibilidade de ser protagonistas em atividades que façam algo pelo povo"38.

Tal protagonismo é o desejo de observar as diversas situações vividas na atual realidade. Para entender o jovem, devemos nos colocar em movimento, sempre abertos ao diálogo e ao novo, devemos nos atentar para os detalhes, deve haver um esforço da sociedade para acompanhar os passos dos jovens.

Diante dessa realidade, os jovens devem se colocar também em constante escuta e atenta participação, pois "um jovem tem algo de profeta e deve se dar conta isso. Deve estar consciente de ter as asas de um profeta, a atitude de um profeta, a capacidade de profetizar, de falar, mas também de fazer." ${ }^{39}$

É mister observar que a sociedade não se encontra mais nos moldes de décadas anteriores; agora, ela é multifacetada, tem inúmeras formas de agir e pensar. A cultura do descarte e a depressão provocam desfavor na vida dos jovens e a comprometem na sociedade. Enquanto profetas, os jovens têm uma missão: “têm que 'sujar os pés' nas estradas, estar entre

\footnotetext{
$36 \mathrm{CV}$, n. 14.

37 Cf. Lc 22, 26.

38 CV, n. 225.

39 FRANCISCO, 2018, p. 37.
} 
outros jovens que precisam de um sentido para a vida e ajudá-los, fazer-se portadores de esperança e descontinuidade em relação aos adultos." ${ }^{40}$

Papa Francisco, com consciência, nos alerta para esta realidade e para a necessidade de observar o mundo e as diversas formas de relações existentes. Ele apresenta o jovem com suas faces, com a capacidade de condenar e de lançar perspectivas:

Eles sabem condenar, mesmo que muitas vezes não expressem muito bem sua condenação. E também têm a capacidade de examinar o futuro e olhar um pouco mais adiante. Mas os adultos muitas vezes são cruéis e isolam toda essa força dos jovens. Os adultos muitas vezes desenraizam os jovens, arrancam suas raizes e, em vez de ajuda-los a serem profetas para o bem da sociedade, os tornam órfãos e desenraizados. Os jovens de hoje estão crescendo em uma sociedade sem raizes. ${ }^{41}$

A vivência do amor humano deve ser refletida em atos constantes de fazer o bem, doar-se e viver a serviço do próximo, não havendo lugar para sentir desgosto pelo bem do outro, como na inveja, mas sim para fazer o bem sem restrições. O sim à família é uma renúncia de si mesmo para a construção do amor. Amar é ser amável e o verdadeiro encontro com o outro requer um olhar amável, que gera vínculos, cultiva laços, cria novas redes de integração.

A pessoa que ama é capaz de dizer palavras de incentivo. O Concílio acrescenta o amor na relação: "o autêntico amor conjugal é assumido no amor divino" 42 . Ou seja, é no amor de Deus para com o ser humano e toda a criação que os cônjuges são chamados a construir a sua vida. $\mathrm{O}$ ensinamento sobre o matrimônio e a família deve se pautar no amor e na ternura para que não se torne algo frio e sem alegria, mas para que o matrimônio se torne algo de grande importância e não "uma convenção social, um rito vazio ou o mero sinal externo de um compromisso. O sacramento é um dom para a santificação e a salvação dos esposos"43.

O amor conjugal não é, portanto, apenas uma qualidade, mas a finalidade do matrimônio. Trazer o sacramento do matrimônio para a modernidade é uma atitude pastoral para o Magistério, que busca enxergar

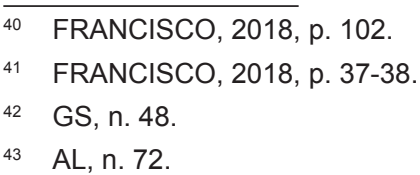


no consentimento dos nubentes a vontade de Deus, a vocação à santidade e o amor de Cristo na sua aliança com a Igreja. Para as futuras gerações, faz-se necessário este retorno à comunhão com Deus e à comunhão no matrimônio.

Nessa realidade, é importante observar a autenticidade na vida e missão dos jovens de todo mundo. Não se deve buscar a santidade para se copiar a vida de algum santo, mas, no seu testemunho e autenticidade cristã, observar a vocação a ser seguida: "Tu tens que descobrir quem és e desenvolver o teu caminho próprio de ser santo, independentemente do que dizem e pensem os outros" 44 .

A família deve ser um ambiente de ternura e amor: Cristo quis vir ao mundo no seio de uma família e se tornou homem. Hoje temos uma realidade, como aponta o Papa Francisco, de uma juventude desenraizada, com as relações frágeis e muitas vezes fragmentada:

uma sociedade composta por pessoas, famílias, que estão pouco a pouco perdendo seus laços, aquele tecido vital tão importante para sentirem-se parte uns dos outros, participantes com os outros de um projeto comum $^{45}$.

A união entre os esposos é elevada, pelo sacramento do matrimônio, a uma familiaridade com Deus em sua totalidade. Francisco deseja ardentemente que os jovens assumam o sacramento do matrimônio, pois, na cultura do descartável, o compromisso matrimonial, apesar de se apresentar como um fardo pesado demais, pois implica em comprometimento e sacrifício, ainda é a saída para os problemas sociais:

é preocupante que hoje muitos jovens não tenham confiança no matrimônio e convivam adiando indefinidamente o compromisso conjugal, enquanto outros põem fim ao compromisso assumido e imediatamente instauram um novo ${ }^{46}$.

Ele justifica a resistência dos jovens ao matrimônio diante da cultura do provisório. Essa característica do mundo pós-moderno cultua apenas a necessidade de uma vida sem compromissos e da satisfação imediata dos próprios desejos e prazeres. O matrimônio começa rapida-

${ }_{44}$ CV, n. 162.

45 FRANCISCO, 2018, p. 38

46 AL, n. 293. 
mente com o atropelamento das fases iniciais da trajetória de maturidade do indivíduo e termina da mesma forma rápida, sem o comprometimento com o "sim" dado ao outro e a Deus.

A Igreja, reforçada pelo magistério do Papa Francisco, quer combater a liquidez das relações com a alegria sacramental. Para tanto, é necessário desamarrar do matrimônio o aparente fardo pesado de pecado e outras tantas questões, mas se deve observar e enaltecer a vocação matrimonial e, consequentemente, a constituição familiar.

Buscar uma relação sadia para a família é essencial, ter a liberdade e ser responsável são atributos imprescindíveis para o discernimento vocacional, pois é com esta proposta que deve caminhar a juventude para que saiba optar na vida sempre com sensatez e inteligência, de forma ética, com padrões humanos e cristãos.

A formação moral deve realizar-se sempre com métodos ativos, pautada no diálogo suscitando em todos a necessidade de descobrir a importância de determinados valores e princípios. Francisco exprime o desejo de uma Igreja que não tenha medo de ser a primeira, que aceite o outro e que não tenha medo de errar. Preocupado com a família no mundo pós-moderno, ele nos apresenta uma Igreja que acompanha e vive com os seus integrantes as suas mazelas e dificuldades, e também se alegra com suas conquistas e glórias.

Para a realidade atual e as relações humanas, Francisco se dedica aos jovens pois sente a juventude atordoada diante de tantas informações, e também se atenta para a cultura do provisório. Francisco apresenta o jovem como um ser cheio de alegria e entusiasmado, a quem não deve faltar o bom humor, que dá alegria e leveza à vida.

É preciso observar as realidades e nos conectarmos aos problemas concretos da juventude, além de não nos fecharmos em nós mesmos, mas sairmos em busca das famílias, escutando, acompanhando e aconselhando.

O Amor é a maior resposta contra a cultura do provisório, pois não se funda no egoísmo nem se finda no sentimento, que é importante, mas não basta. $\mathrm{O}$ amor atitude é que sustenta, em Deus, o relacionamento em sua proposta de ser eterno. A insegurança em se lançar no comprometimento matrimonial é dirimida com o convite a se tornar uma só carne e viver a união conjugal. 


\section{Considerações finais}

O desejo do envolvimento pastoral da Igreja, frente às dificuldades enfrentadas pela juventude e a família no mundo de hoje, aparentemente pode soar como uma "autoajuda", na intenção de apresentar opções para lidar com as dificuldades do dia-a-dia. Mas isso é aspecto marcante desde o início do pontificado de Francisco.

De fato, o indivíduo que age de forma ética, buscando sua consciência, não pode ser entendido com um ser com a mentalidade fraca ou omissa. Ele é rico em criticidade, pois busca o discernimento de suas ações, mediante a análise de sua vida e a sociedade em que vive. Nessa realidade, a Igreja deve buscar sempre fomentar, nos mais jovens, o desejo pela vocação matrimonial, pois é da família que saem todas as vocações.

Voltar-se à questão dos jovens, que devem estar atentos às escolhas da vida e serem encorajados a optar pelo matrimônio, é importante para ressaltar a necessidade de um período pré-matrimonial bem vivido para tentar conhecer o outro com quem se pretende relacionar-se para o resto da vida.

É mister apresentar a realidade vivida, principalmente que o Magistério não deseja apresentar uma nova doutrina da Igreja sobre matrimônio e família, mas se coloca atento às possibilidades de uma visão misericordiosa com as famílias em geral.

O Magistério pós-conciliar aponta ainda que a doação em prol do amor conjugal não pode simbolizar perda ou martírio, nem a abdicação total do desejo e do prazer. Colocar-se à disposição do outro é um caminho de renúncias pautadas nas transformações do interesse pessoal em bem comum.

De fato, é importante o acolhimento e buscar o discernimento para os jovens e suas distintas realidades. A Igreja deve estar atenta a todos, principalmente aos mais fragilizados. O matrimônio cristão, sacramento da união entre Cristo e a sua Igreja, realiza-se plenamente na união entre um homem e uma mulher, que se doam reciprocamente, se abrem à procriação e à constituição de uma igreja doméstica.

A relação matrimonial tem sua perspectiva voltada para a santidade, assumindo um compromisso para toda a vida. A vocação humana se confirma em um amor que se faz doação, que tem por fim uma pessoa, que é o amor por excelência e que se doou por completo para a humanidade. 


\section{Referências}

BÍBLIA DE JERUSALÉM. São Paulo: Paulus, 2003.

CONFERÊNCIA NACIONAL DOS BISPOS DO BRASIL. Evangelização da Juventude: Desafios e perspectivas pastorais. São Paulo, Paulinas, 2007.

CONSTITUIÇÃO Dogmática Lumen gentium sobre a Igreja. In: COMPÊNDIO DO VATICANO II. Constituições, Decretos, Declarações. Petrópolis: Vozes, 1996. p. 37-117.

CONSTITUIÇÃO Pastoral Gaudium et spes sobre a Igreja no mundo atual. In: COMPÊNDIO DO VATICANO II. Constituições, Decretos, Declarações. Petrópolis: Vozes, 1996. p. 141-256.

FRANCISCO. Exortação Apostólica Evangelii Gaudium sobre o anúncio do evangelho no mundo atual. São Paulo: Paulinas, 2015.

. A família que gera o mundo: as catequeses de quarta-feira. São Paulo: Paulus, 2016.

. Exortação Apostólica Pós-sinodal Amoris Laetitia sobre o amor na família. São Paulo: Paulinas, 2016.

. Deus é jovem: uma conversa com Thomas Leoncini. São Paulo: Planeta do Brasil, 2018.

. Exortação Apostólica Pós-sinodal Christus Vivit.São Paulo: Paulinas, 2019.

SÍNODO DOS BISPOS. III Assembleia Geral Extraordinária do Sínodo dos Bispos, Relatio Synodi (18 de Outubro de 2014). Disponível em: <http://www.vatican.va/roman_curia/synod/documents/rc_synod_doc_20141018_relatio-synodi-familia_po.html>. Acesso em: 16 abr. 2019 .

. XV Assembleia Geral Ordinária. Os jovens, a fé e o discernimento vocacional. Documento Final. 2018. Disponível em: $<$ http://www. vatican.va/roman_curia/synod/documents/rc_synod_doc_20181027 doc-final-instrumentum-xvassemblea-giovani_po.html>. Acesso em: 23 abr. 2019. 